\title{
PROSES PENYUNTINGAN BERITA PADA PERUSAHAAN JAWATAN TELEVISI REPUBLIK INDONESIA (TVRI) BENGKULU
}

\author{
Oleh : \\ Sapta Sari \\ Dosen Tetap Prodi Ilmu Komunikasi Fakultas Ilmu Sosial Universitas Dehasen Bengkulu
}

\begin{abstract}
In line with times, television news center has been equipped with a variety of sophisticated tools, such as the ones used in the production and editing process of the Company Bureau (PERJAN) TVRI Bengkulu. Some of the tools used were: ENG (Electronic News Gathering), a large movie camera (Sound On Film) electronic editing tools, broadcasting space, VTR space, and various other supporting tools that are used to improve the quality of broadcasting. In this research, researchers used a qualitative descriptive approach by interview, observation and documentation, followed by data analysis. The result of this research found that the process of delivering news on TVRI Bengkulu, particularly on program Bengkulu dalam Berita, has been carried out by adjusting the news delivery technique through two ways: ie the way the British were serious and formal and casual events of the United States. Both methods have been implemented in the event of this program.
\end{abstract}

Keywords: editing process, news

\section{PENDAHULUAN}

Informasi sangat diperlukan oleh manusia, karena dengan informasi masyarakat akan mengetahui kejadiankejadian di belahan dunia yang secara jarak dan waktu akan sulit didapati jika tanpa media yang mampu menjembataninya. Penemuan televisi pertama kali bermula dengan ditemukannya Electrishe Teleskop sebagai perwujudan gagasan seorang mahasiswa dari Berlin, Paul Nipkov untuk mengirim gambar melalui udara dari satu tempat ke tempat lain. Hal ini terjadi antara tahun 1983 sampai 1884. Oleh karena itu Paul Nipkov diakui dunia sebagai bapak televisi. (J.B Wahyudi 1983:1)

Televisi Republik Indonesia (TVRI) lahir pada tanggal 24 Agustus 1962. Pada waktu awal keberadaannya, modal siaran berita hanya berupa kamera film $16 \mathrm{~mm}$, alat cuci film yang sederhana, alat pengering yang sederhana dan juga alat penyunting buatan sendiri secara tradisional. Film yang digunakan masih film negatif dan warna hitam putih yang juga dilengkapi dengan foto tustel guna menunjang mencari gambar. (JB.Wahyudi 1983:2)

Siaran perdana TVRI dilaksanakan saat melakukan siaran Asia Games IV di Jakarta. Sebagai lembaga penyiaran, kehadirannya tidak disiapkan secara wajar. Tidak ada penelitian dilapangan terhadap faktor pendukung maupun kendala yang akan dihadapi. Bahkan, agar menonton siaran dari rumah, pemerintah membagibagikan sejumlah pesawat televisi kepada khalayak terbatas.

Sejalan dengan perkembangan zaman, pusat pemberitaan televisi telah dilengkapi 
dengan berbagai alat-alat yang canggih, seperti halnya yang digunakan pada proses pembuatan dan penyuntingan pada Perusahaan Jawatan (PERJAN) Televisi Republik Indonesia (TVRI) Bengkulu. Alatalat yang digunakan diantaranya adalah ENG (Enlektonik News Gathering), kamera film besar (Soun On Film,) alat editing elektronik, ruang siaran, ruang VTR (Vidio Television Record) serta alat-alat pendukung lainnya yang peralatan itu diadakan untuk meningkatkan mutu siaran.

Kegiatan pemberitaan tampak sederhana jika dilihat secara sekilas. Wartawan mencari berita, menulis, serta menyiarkan berita. Tetapi dilihat lebih mendalam tentu tidaklah tepat jika pandangan tersebut dikemukakan, sebab setiap berita mencakup teknik dan bidang siaran, harus bekerja dengan baik sesuai dengan syarat-syarat berita dan teknik penyampaian gambar dan suara yang telah ditetapkan.

Adapun syarat-syarat berita meliputi: Baru, Aktual dan Penting. Masalah ini penting untuk mencegah adanya kemungkinan kesalahan seperti suara tidak sesuai dengan gambar yang ditampilkan, gambar dan suara tidak bisa dilihat dan didengar, serta kesalahan lainnya. Keadaan ini akan terus terpuruk tiap kali siarannya jika tidak dilakukan teknik yang tepat.

\section{METODE PENELITIAN}

Dalam Penelitian ini menggunakan metode kualitatif. Metode interview atau wawancara adalah metode yang dilakukan dengan cara tanya jawab, baik langsung maupun tidak langsung dengan sumber data. Lebih jelas Mohammad Ali,Phd (1982:45) mengatakan interview atau wawancara adalah proses keterangan untuk tujuan penelitian dengan tanya jawab sambil bertatap muka secara langsung atau tidak langsung antara responden atau pewawancara dengan si penanya jawab yang menggunakan alat interview guide atau panduan wawancara. Sejalan dengan pendapat di atas maka yang dimaksud dengan interview atau wawancara adalah satu metode pengumpulan data dengan cara bentuknya tanya jawab, sambil bertatap muka langsung ataupun tidak langsung antara peneliti dengan responden.

Studi kepustakaan dalam rangka mencari data yang lebih menunjang penelitian ini yaitu dengan cara membaca dan mengutip pendapat para ahli. Beberapa literatur yang berhubungan dengan masalah yang diteliti. Metode observasi atau pengamatan yakni metode pengumpulan data dimana penelitian melakukan pengamatan langsung terhadap gejala-gejala atau peristiwa-peristiwa atau bentuk-bentuk kegiatan terhadap subjek atau objek penelitian, baik pengamatan yang dilakukan dadalam situasi sebenarnya maupun dilakukan didalam situasi bantuan yang khusus diadakan.

Teknik analisis data dalam penulisan ini penulis menggunakan metode analisis deskriptip. Metode deskriptif bertujuan melukiskan secara sistematis fakta atau karakteristik populasi atau bidang tertentu secara faktual dan cermat. (Wahya dan Muhammad, 1907:42). Dalam pengolahan data dan analisa melalui metode diskriptif, penulis mengambil data yang sebenarnya yang sesuai dengan kenyataan yang ada juga, sesuai dengan tujuan penelitian ini. Data yang telah terkumpul lalu diuraikan secara terperinci sesuai dengan kenyataan yang ada yang berbentuk kalimat.

\section{HASIL PENELITIAN DAN PEMBAHASAN}

\section{Proses Penyuntingan Berita Pada TVRI Bengkulu}


Setiap berita yang masuk kepusat pemberitaan TVRI harus diseleksi, apakah cerita itu memenuhi syarat disiarkan atau tidak, berita yang dapat disiarkan harus memenuhi persyaratan, yakni penting (important), menarik (interesting), masi baru (actual), serta aman disiarkan (security).

Sebenarnya syarat berita yang paling utama adalah penting dan masih baru,tetapi untuk TVRI Bengkulu perlu memasukkan unsur security dalam pemilihan berita karena media Televisi Republik Indonesia Bengkulu tunduk pada azas yang dianut oleh pers nasional, yaitu pers yang bebas tetapi bertanggung jawab.

Pers bebas bertanggung jawab ini berarti kebebasan mengemukakan pendapat harus disertai rasa tanggungjawab terhadap bangsa, negara dan Tuhan Yang Maha Esa. Arti kebebasan di Indonesia dilandasi oleh falsafah bangsa Indonesia yaitu Pancasila. Untuk itulah pusat pemberitaan TVRI maupun urusan pemberitaan di stasiun TVRI Daerah Bengkulu tidak akan menyiarkan berita-berita yang dapat menimbulkan keresahan dikalangan masyarakat, seperti SARA, yaitu suku, agama, ras, dan antar golongan. Meskipun berita itu memenuhi syarat menarik dan masih baru.

Dalam menyangkut masalah penerangan dan media massa TVRI Bengkulu menggelorakan semangat pengabdian dan perjuangan bangsa, memperkokoh persatuan dan kesatuan nasional, memasyarakatkan kebudayaan dan kepribadian Indonesia serta menggairahkan partisipasi masyarakat dalam pembangunan. Ini adalah beban berat yang dipegang media elektronik, khususnya televisi. Untuk itu diperlukan suatu pekerjaan yang teliti mulai dari reporter, cameraman, dan EIC yang berfungsi untuk menyunting naskah.

Penyuntingan dalam media televisi diartikan adalah suatu pekerjaan menyambung, menambah dan membuang naskah dan hasil shooting, baik dilapangan maupun di studio sehingga hasilnya merupakan suatu jalinan atau urutan yang bisa dinikmati dan dimengerti pemirsa televisi. Sebelum pekerjaan penyuntingan dilaksanakan, seorang reporter dan kameraman diutus untk mencari berita, (hunter) baik itu berita yang soft news ataupun hard news.

Dalam pembuatan naskah, seorang reporter harus memperhatikan unsur-unsur berita, Kode Etik Jurnalistik, serta hal-hal lain yang tidak menyebabkan kerancuan bagi penerima berita yang dibuat reporter/wartawan. Dalam penulisan berita yang perlu diperhatikan yakni penggunaan bahasa. Bahasa dalam pembuatan suatu berita memengang peranan yang penting, sebab dalam bahasa berita disamping harus jelas juga mudah dimengerti oleh khalayak.

Penggunaan kata dalam penulisan berita harus memperhatikan unsur SARA, sebab disuatu daerah mungkin kata yang ditulis reporter/wartawan tersebut sudah lumrah didengar dan digunakan, sedangkan di daerah lain kata-kata tersebut tabu untuk dibicarakan. Seperti kata 'labu' dalam masyarakat Bengkulu, perkataan tersebut merupakan hal yang tabu, padahal dalam penggunaan bahsa Indonesia itu sudah biasa untuk diucapkan dan digunakan.

Disamping itu penulisan berita harus singkat, padat dan jelas. Dalam aturan berita jangan terlalu panjang, dan utamakan berita yang penting terlebih dahulu dari pada berita yang kurang penting. Sebab berita yang kurang penting, dalam berita televisi bermain dengan waktu. Dengan kata lain dengan waktu yang singkat seorang wartawan/reporter harus membuat berita yang lengkap dan jelas. Yang perlu di sunting/edit dalam berita televisi adalah gambar yang ditampilkan. Untuk mengerjakan ini diperlukan seorang yang mengerti tentang teknis peralatan maupun tentang isi dan visi dari gambar yang di tampilkan. Orang yang tugasnya 
mengerjakan editing/penyuntingan gambar disebut Audioman Editor atau dalam bahasa Indonesia disebut penyuntingan gambar. Cameramen dan reporter hendaknya dalam penyuntingan ini harus selalu berkoordinasi (kerjasama) untuk mengambil dan menampilkan gambar yang bagus untuk ditampilkan. Pengambilan gambar dilapangan harus pula memperhatikan isi berita yang akan dibuat, biasanya dalam pengambilan gambar ini khususnya di TVRI Bengkulu yang memegang peranan dalam mengambil gambar dan suara adalah reporter/wartawan.

Pada berita televisi, gambar berupa pendukung yang utama. Sebab dalam dunia pemberitaan khususnya televisi, reporter dan cameramen merupakan orang yang benarbenar tahu terhadap berita yang disajikan. Seorang pemirsa televisi biasanya ingin sekali bagaimana melihat gambar pada pemberitaan yang disajikan, sebagai contoh berita yang ditampilkan mengenai gempa bumi yang terjadi di Provinsi Bengkulu beberapa tahun yang lalu, disini seorang cameramen mengambil gambar berupa jumlah korban, bentuk kerusakan yang mengakibatkan gempa, statemen dari Badan Metereologi dan Geofisika (BMG) mengenai besarnya kekuatan gempa serta gambar-gambar lain yang sangat mendukung berita tersebut.

Adapun proses penyuntingan berita pada media TVRI Bengkulu dilakukan dengan 2 cara yakni :

Proses Penyuntingan Pada Naskah Berita Reporter ditugaskan ke lapangan untuk mencari berita (hunter); Dalam proses pertama ini, reporter ditugaskan untuk mencari berita ketempat-tempat yang dimungkinkan mendapatkan berita. Seperti kantor polisi, kantor pengadilan dan tempat lain yang sebelumnya sudah memberitahukan bahwa ditempatnya ada acara baik seminar ataupun acara serimonial lainnya.

\section{Melaporkan Kegiatan Hunter} kepada Editor In Chip (EIC); Setelah meliput berita dilapangan, seorang reporter harus melaporkan kegiatan hasil dilapangan, yakni berupa berita yang didapatkan kepada EIC, dan dilanjutkan dengan langkahlangkah: (a) Mengetik Berita, seorang reporter pada saat membuat berita, harus memperhatikan ketentuan pembuatan berita yakni $5 \mathrm{~W}+1 \mathrm{H}$, Kode etik Jurnalistik, serta unsur-unsur berita. (b) Menyunting Naskah Berita (Editor In Clip). Dalam hal ini berfungsi untuk menganalisa berita yang dibuat reporter, proses ini sangat penting dalam penyuntingan berita, sebab dalam penyuntingan terrsebut seorang EIC harus jeli dalam memilih kata-kata yang pas untuk berita tersebut, mengecek kelengkapan berita, serta dampak yang diakibatkan dari pemberitaan tersebut.

\section{Proses Penyuntingan berita pada Audio dan Visual}

Seorang kameraman pada saat shooting tersebut harus membawa kelengkapan peralatan seperti kamera, baterey, lampu, alat perekam, mikrofon serta alat-alat lain yang mendukung saat shooting.

Disamping itu seorang kameraman harus pandai memanfaatkan waktu yang pendek untuk mengambil gambar dan suara yang diinginkan reporter. Dalam proses pengambilan gambardan suara diperlukan ketenangan dan sikap yan siap untuk shooting, agar hasilnya sesuai yang diinginkan reporter dan masyarakat pada umumnya.

Berikut secara rinci proses penyuntingan gambar dan suara (a) Kameraman diutus untuk shooting; Dalam proses pertama ini seorang kameraman diutus Assisten Manager teknik unutk shooting guna melengkapi berita diambil reporter. (b) Melapor pada Assisten Manager Teknik; Pekerjaan kedua ini seorang cameramen setelah pulang shooting, ia melaporkan kegiatan pada 
Assisten Manager Teknik mengenai tempat shooting dan hal lainnya yang berhubungan dengan kegiatan shooting. (c) Mentransfer Hasil Shooting; Pekerjaan selanjutnya yakni menstransfers kegiatan hasil shooting kedalam sebuah kaset untuk direkam. (d) Proses perekaman dan pengisian suara; dalam hal ini seseorang mengisi suara (Dubbing) membacakan berita mulai dari VCR STAR sampai dengan habis. Untuk proses dubbing ini apabila terdapat

\section{Cara Penyampaian Berita Pada TVRI Bengkulu}

Pada media televisi, faktor penyaji/penyiar berita memang berperan penting dalam penyampaian naskah berita kepada khalayak, agar isi berita dapat sampai kepada khalayak secara jelas. Didunia penyiaran, penyampaian berita dapat dilakukan oleh penyiar berita maupun oleh reporter. Paling ideal adalah jika seorang penyiar berita bertindak sebagai reporter. Orang yang pekerjaannya reporter dan penyiar ini disebut newscasters. akan tetapi, tidak semua reporter dapat menjadi penyiar berita, sedangkan semua penyiar semua reporter dapat menjadi penyiar berita, sedangkan semua penyiar berita dapat menjadi reporter. Untuk menjadi penyiar berita, seorang reporter harus memiliki persyaratan khusus dibidang penampilan dan volume suara.

Orang yang membaca berita disebut News Readers ini biasanya tidak memahami isi berita, dan tidak menjiwai apa yang akan dibawakannya. Sedangkan seorang Newscasters selain menyajikan berita, juga menjiwai apa yang akan dibawakan karena pada dasarnya dia juga seorang reporter.

Adapun fungsi dari newscasters sama dengan anchor (pembawa acara). Perbedaannya, newscasters bersifat formal, sedangkan anchor lebih bersifat non-formal. Bebas tetapi tetap berwibawa. Setiap kata dan informasi yang diucapkan selalu kesalahan dalam pengucapan kata, pengurangan dan penambahan kata maka proses pengisian suara harus diulang, pada bagian yang salah atau diulang dari awal. (e) Pemotongan suara dan gambar di lapangan; Pemotongan suara dan gambar ini tentu saja berdasarkan keinginan dari reporter,untuk memilih dan menempatan bagian manayang layak untuk mendukung kelengkapan sebuah berita.

mengandung nilai intelektualitas dan bukan informasi yang sudah diketahui oleh masyarakat umum.

Televisi Republik Indonesia Bengkulu lebih banyak menggunakan cara Inggris dalam penyampai berita, sedangkan Televisi Swasta lebih banyak menggunakan cara-cara yang berkembang di Amerika serikat. Hal ini wajar karena TVRI Bengkulu adalah mass media pemerintah sehingga harus berpenampilan formal. Sedangkan televisi swasta lebih bersifat bebas.

Adapun persyaratan utama untuk menjadi seorang penyiar berita adalah sebagai berikut : Memiliki Intelektualitas yang tinggi, memiliki penampilan fisik dan volume suara standar, memiliki kepribadian kuat. Menjadi penyiar berita, seperti penyiar artistic, dasarnya adalah bakat. Tanpa memiliki bakat seseorang tidak akan mampu menjadi penyiar professional khususnya penyiar berita yang harus memiliki pengetahuan dan keterampilan jurnalistik. Jadi untuk menjadi seorang penyiar berita (baik Newscasters maupun anchor) tidak perlu harus cantik atau gagah, tetapi harus wajar dan berwibawa.

Seorang penyiar (baik penyiar artistic maupun penyiar berita) memahami betul kemampuan dirinya sehingga mampu mengantarkan dirinya kepuncak karier sebagai penyiar professional, seseorang akan mengundurkan diri dengan sendirinya 
mungkin karena faktor usia sehingga mengurangi daya intelektualitasnya.

Menurut Boyd (1990) seorang penyiar/penyampai berita harus memiliki diantaranya : Kredibilitas, Kejelasan dan Kejernihan suara, Komulatif, Berkepribadian yang kuat, Professionalitas yang tinggi, Penampilan dan volume suara yang standar.

Diluar negeri seperti di Amerika Serikat dan Inggris, seorang penyampai atau penyiar berita diseleksi di wartawan cetak atau reporter radio atau televisi, sehingga mereka sudah menguasai dasar dan bahan sudah mempraktekkan keterampilan Jurnalistik. Di Indonesia justru terbalik, pertama tama merekrut para calon penyiar yang memenuhi persyaratan intelektualitas, penampilan, volume suara dan kepribadian, kemudian baru diberikan pengetahuan dan keterampilan jurnalistik.

Teknik lain yang digunakan Televisi dalam penyampaian berita, yakni sistem Reporter On the ON The Screen (ROSS) yang meliputi : Memiliki wajah yang berwibawa, tidak memiliki gerakan-gerakan yang aneh atau tidak biasa diwajah, memiliki volume suara yang standar, menguasai permasalahan yang disajikan, intelek dan professional, berpenampilan sopan dan sesuai situasidan kondisi yang ada.'

Pada media Televisi Republik Indonesia Bengkulu menyampaikan berita dilakukan dengan dua cara yakni sebagai berikut : (1) Cara yang dikembangkan di Amerika Serikat, disini penyampaian berita dikemas dengan filosofi smile, atau bersifat santai, dalam arti tidak harus selalu tegang. Oleh karena itu, di Amerika Serikat dipakai istilah anchor yang berarti telangkai, yang maknanya perangai.

Cara penyampaian seperti ini dilaksanakan santai walaupun berita yang penyiar ssampaikan tersebut berita keras (Hard news). Seperti contoh Berita kebakaran besar yang menimpa daerah Jakarta Pusat. (2) Cara yang dikembangkan di Inggris, cara penyampaian berita seperti ini berfilisofi adalah serius (scowl), dengan berasumsi bahwa sifat berita adalah formal.

Dalam penyampaian berita cara inggris ini, seorang penyiar harus bersikap serius dalam menyampaikan berita meskipun berita yang dibawahkan tersebut bersifat santai, seperti contoh berita human interest, yang cara penulisannya banyak menggunakan daya khayal penulis seolaholah penonton berada ditempat kejadian tersebut.

Dari dua penyampaian berita diatas seorang penyiar harus pandai-pandai kapan kedua model berita tersebut digunakan. Untuk itu seorang penyiar harus bisa di tuntut belajar memahami setiap berita yang masuk kemeja redaksi. Seorang penyiar atau penyampai berita yang baik biasanya sebelum acara dimulai, ia datang satu jam sebelum acara dimulai. Kedatangannya penyiar lebih cepat ini dimaksudkan tidak lain adalah untuk lebih memahami berita yang ia akan sampaikan.

\section{Cara Menyelaraskan Berita Gambar Dan Suara}

Dalam menyelaraskan antara pemberitaan gambar dan suara diperlukan ketelitian dari seorang Audioman yang berfungsi untuk memotong bagian mana yang tidak layak untuk disiarkan.

Jika pemberitaan gambar dan suara tidak disesuaikan dengan naskah, maka akan berakibat pemberitaan yang kurang baik dan timbul protes dari masyarakat. Gambar dan suara dalam pemberitaan televisi merupakan bagian terpenting dari sebuah berita, tanpa keduanya kelengkapan berita yang reporter/wartawan tersebut tidaklah baik.

Seorang Audioman yang berkerja di ruangan VTR, biasanya menyelaraskan pemberitaan dengan melihat naskah berita. Maka untuk pembuatan naskah sebuah berita 
harus diketik tiga rangkap yang gunanya untuk penyiar, arsip dan audioman.

Di TVRI Bengkulu, biasanya terdapat dokumen rekaman yang bersifat umum artinya dokumen tersebut berisikan tentang keadaan kota dan daerah yang ada di provinsi Bengkulu, seperti dokumen perkebunan, pasar objek wisata, tambang dan sebagainya.

Dengan dimilikinya rekaman tersebut, diharapkan berita yang ditulis reporter/wartawan tidak perlu lagi untuk shooting langsung kelapangan. Seperti contoh jika yang di beritakan tersebut masalah turun harga pertanian seperti kopi, jahe, kelapa sawit, dan sebagainya. Maka rekaman yang terdahulu sudah ada, tinggal hanya memutar lagi hasil rekaman pertanian tersebut, sehingga berita yang dibuat wartawan selaras dengan berita gambar.

Permasalahan ini sering kita lihat seperti untuk melihat pemberitaan atau mendukung berita tersebut perlu dibuat peta atau tempat kejadian, sehingga masyarakat atau pemirsa kurang puas tehadap berita yang disajikan karena tidak ada gambar kejadian tersebut. Untuk itu dengan dimilikinya dokumen ini suatu stasiun penyiaran tidak akan kesulitan dalam membuat berita yang reporter dan kameraman tidak terjun kelapangan untuk hunter.

Sebelum berita ditayangkan ke khalayak pemirsa, seorang kameraman dan reporter saling berkoordinasi untuk memotong bagian mana diantara suara dan gambar yang layak ditampilkan dan tidak layak untuk ditampilkan. Adapun cara yang digunakan untuk menyelaraskan berita gambar dan suara yakni sebagai berikut (1) Cara Teknik; Seorang cameramen memberikan kode Q IN setiap gambar dan suara berita yang akan ditampilkan, lalu bagian yang Q IN ini yang akan ditayangkan. Sebaliknya jika ingin membuang bagian gambar dan suara yang tidak unutk ditayangkan maka seorang kameraman menggunakan tanda Q OUT. (2) Cara Penyesuaian Terhadap Naskah Berita; Adapun cara menyelaraskan berita yang akan ditampilkan yakni berdasarkan naskah berita yang ditulis. Sebagai contoh jika yang diberitakan Gubernur Bengkulu meresmikan Rumah Sakit, maka gambar tanda tangan peresmian serta sambutan yang diberikan Gubernur terhadap diresmikannya Rumah Sakit tersebut. Dalam penulisan naskah berita ditulis statement, ini berita yang ditampilkan adalah orang yang diwawancarai oleh reporter dilapangan yang mendukung berita tersebut.

\section{PENUTUP}

\section{Kesimpulan}

Berdasarkan hasil penelitian dan analisa data yang telah ditemukan diatas, maka dapat ditarik kesimpulan sebagai berikut : (1) Proses penyuntingan berita pada media Televisi Republik Indonesia (TVRI) Bengkulu sudah dilaksanakan dengan baik ini terbukti sudah dilaksanakan penyuntingan tiap berita yang masuk sebagaimana prosedur yang diterapkan. (2) Proses penyampaian berita pada TVRI Bengkulu telah dilaksanakan dengan menyesuaikan teknik penyampaian berita melalui dua cara yakni cara Inggris yang formal dan serius dan acara Amerika Serikat yang santai. Contohnya kedua cara ini sudah dilaksanakan pada acara Bengkulu Dalam Berita. (3) Proses penyelarasan antara gambar dan suara yang ditayangkan oleh TVRI Stasiun Bengkulu dapat dikatakan telah cukup memadai ini dapat terlihat dari keselarasan antara gambar dan suara dalam acara Bengkulu Dalam Berita tengah berlangsung. 


\section{Saran}

Dari hasil penelitian proses penyuntingan berita pada media TVRI Bengkulu sudah baik. Oleh karena itu kepada semua pihak yang bekerja pada PERJAN TVRI Bengkulu, penulis sarankan kiranya hal-hal yang baik ini paling tidak dipertahankan. Proses penyampaian berita TVRI Bengkulu sudah dilaksanakan baik untuk itu diharapkan kepada penyiar untuk meningkatkan prestasinya agar pekerjaannya menghasilkan sesuatu yang bermutu dan berguna bagi pemirsa TVRI Bengkulu. Dalam menyelaraskan pemberitaan gambar dan suara sudah dilaksanakan dengan cukup memadai untuk itu diharapkan dengan hasil yan demikian dapat dipertahankan. Dengan terbatasnya alat yang ada di TVRI Bengkulu, diharapkan nantinya dapat ditambah baik jumlah ataupun kualitasnya.

\section{DAFTAR PUSTAKA}

Abrar,Ana Nadhya. 1995. Mengurai Permasalahan Jurnalistik, PT. Pustaka Sinar Harapan, Jakarta

Assegaf, Djafar. 1987. Jurnalistik Masa Kini, Ghalia Indonesia, Jakarta

Effendi, Dadan. 1993. Kamera Vidio. Karya Anda, Surabaya
Khalik, Adran. 2001. Diktat Kuliah Strategi Penyuntingan Berita, Bengkulu

Maudalis. 1989. Metode Penelitian. Bumi Aksara, Jakarta, 1989

Mulyana, Dedy dan Ibrahim, Idi Sobandy. 1997. Bercinta dengan Televisi. PT. Remaja Rosdakarya, Bandung

Siregar, Syarifudin. 2000. Diktat Kuliah Seleksi Penyuntingan Berita. Bengkulu

Wahyudi, JB. 1996. Dasar-dasar Jurnalistik Televisi dan Radio. PT. Pustaka Sinar Harapan, Jakarta

Wahyudi, JB. 1984. Jurnalistik Televisi. Alumni, Bandung, 1984 